\title{
Planktonic spermatophores found in a culture device with spionid polychaetes
}

\author{
W. GREVE \\ Biologische Anstalt Helgoland (Meeresstation); \\ Helgoland; Federal Republic of Germany
}

KURZFASSUNG: Planktonische Spermatophoren aus einem Kultursystem mit Spioniden (Polychaeten). Aus Evertebratenlarven, die als Futter für Pleurobrachia pileus (Ctenophora) in einen "Planktonkreisel", ein Hälterungssystem mit Sandinnenfilter, gebracht worden waren, entwickelte sich eine hauptsächlich aus Polychaeten bestehende Bodenfauna. Von dieser wurden pelagische Spermatophoren abgegeben, die nach den erhaltenen Kriterien (Bestimmung des am Ort der Spermatophorenabgabe gefundenen Polychaeten, Form der Spermien) von Spio filicornis (Spionidae) stammten. Die Beobachtungen konnten nicht wiederholt und die Spermienaufnahme durch andere Polychaeten nicht beobachtet werden. Indirekte Spermatophorenübertragung ist bisher im marinen Bereich nur bei Halacariden beschrieben worden.

\section{INTRODUCTION}

One of the problems for sedentary organisms in marine habitats is the difficulty of bringing together their sexual products in order to assure the propagation of the species. In the littoral zone some organisms - especially algae - synchronize the liberation of female and male gametes with the incoming tide. The cirripedes living in the tidal zone and in deeper water develop extremely long penes and the polychaete Eunice viridis, for example, ensures fertilization by the synchronized swarming of its anterior body parts filled with gonoproducts. For species of low population density the fertilization of their eggs may be one of the weakest links in the chain of their ecological requirements. In this light a peculiar spermatophore found under laboratory conditions seems worth reporting.

\section{OBSERVATIONS}

In a series of experiments carried out with the ctenophore Pleurobrachia pileus in the "planktonkreisel", a cylindrical culture vessel with circular flow (GREve 1968), after several months of feeding with marine plankton, a bottom fauna developed from the invertebrate larvae which were not consumed by the ctenophores. Among the organisms living in the ctenophore culture vessels many polychaetes were present, 
most of which belonged to the family Spionidae. While looking for ctenophore eggs in one of the vessels I detected extraordinary objects of a similar size and transparency.

The objects looked very much like toy balloons, the "balloon" itself being very transparent, more or less spherical and approximately $1.6 \mathrm{~mm}$ in diameter with a pedicle, about $1.5 \mathrm{~mm}$ long, protruding from the "balloon's" smaller pole. From the small protrusion point a short finger-shaped prolongation projects into the "balloon". The pedicle itself has its greatest diameter close to the protrusion point where a discshaped portion gives the pedicle a characteristic appearance. It then narrows to the distal end. With the exception of the finger-shaped prolongation, which is greenish white, the whole object is transparent.

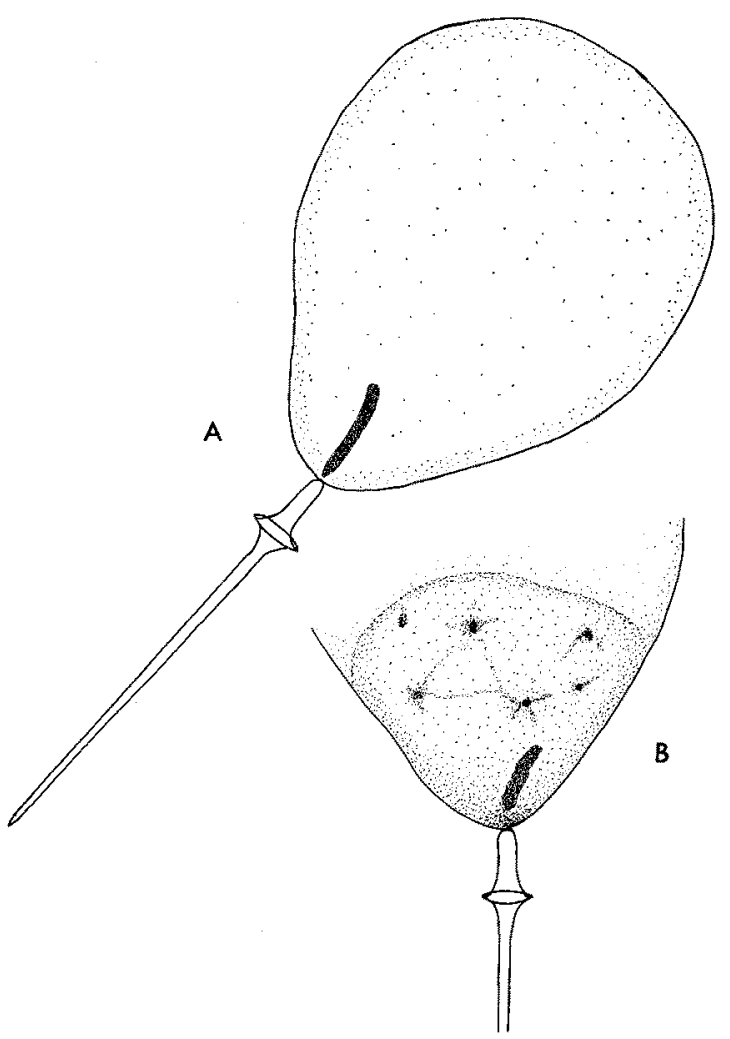

Fig. 1: The planktonic spermatophore. Total length: $3.1 \mathrm{~mm}$. $A$ shortly after liberation the finger-shaped portion has bold outlines. $B$ hours later the sperms aggregate at the walls, the finger-shaped portion loses its shape

The objects were pipetted into fingerbowls and onto slides for investigation. During this procedure they were easily destroyed as they are very delicate.

In the fingerbowls and under the microscope the finger-shaped prolongation soon lost its shape. I found that this was due to spermatozoa which aggregated in the 
finger-shaped prolongation; they were activated by the lights, swarming to the walls of the "balloon" (Fig. 1).

The spermatophores were never found singly. They always appeared in numbers of about 10 or 20 . As it was not known from which species in the container these spermatophores were derived, the bottom fauna was watched every half hour for 5 days and evenings after the plankton organisms had been removed.
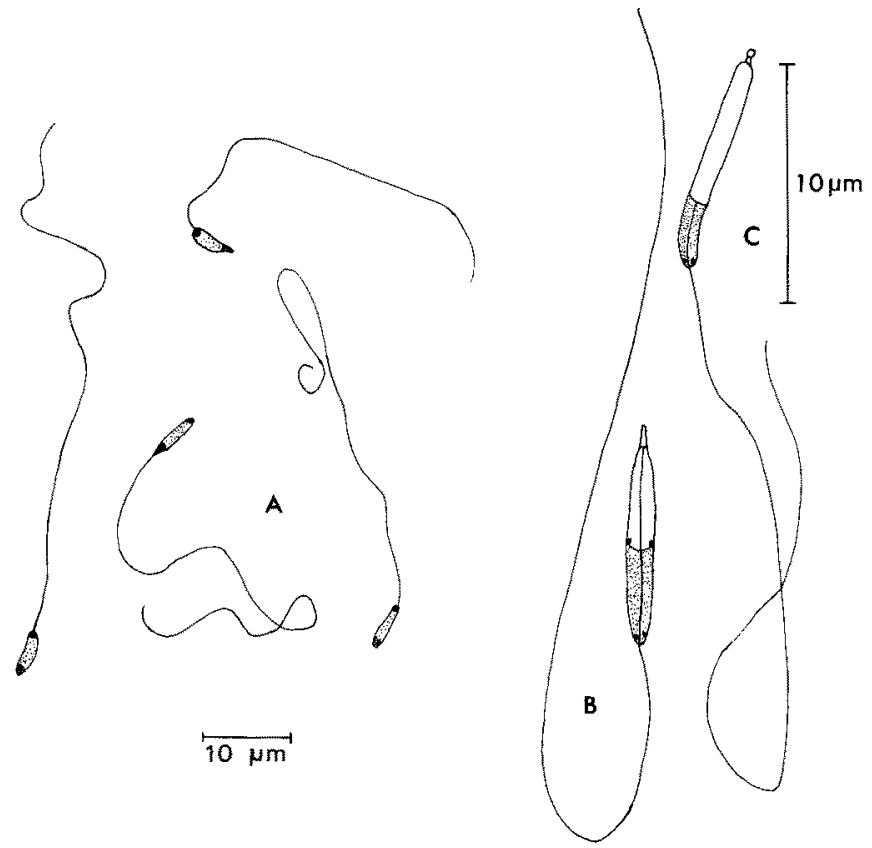

Fig. 2: Comparison of spermatozoa. A Spermatozoa, found in the planktonic spermatophore. $B$ Spermatozoon of Polydora ciliata. C Spermatozoon of Pygospio elegans. (After Franzen 1956, modified)

Only once did I observe a bundle of 10 spermatophores being pushed out of the sand. With a fingerbowl this part of the sand filter was scooped out of the vessel at once. The only animal larger than $1 \mathrm{~mm}$ found was a spionid polychaete of about $1 \mathrm{~cm}$ in length. It was kindly identified by WestheIDE as $S$ pio filicornis. This identification is supported by the morphology of the spermatozoa which are very similar to those of the closest relatives of this spionid described by Franzen (1956). It is almost certain, therefore, that Spio filicornis produced these spermatophores (Fig. 2).

As I expected also some 90 of Spio filicornis to be living in the culture vessels and that they might attempt to capture the spermatophores the observation was continued. The spermatophores usually drifted through the water with the pedicle downwards. It is possible that in nature they drift over the sand surface like a "woodhead" sea-bed drifter; yet the "planktonkreisel" was designed to blow the planktonic organisms away from the bottom into the water. Thus the spermatophores were found 
at any depth and had only little contact with the bottom-living spionids. An attempt was made to bring the spermatophores artifically into contact with these polychaetes, but none of the spionids filtering the water above the sand-water interface reacted upon the contact with a spermatophore.

\section{DISCUSSION}

The sexual behaviour of polychaetes is almost unknown according to WESTHEIDE \& Ax (1964), who stated that they are the first to describe the transfer of spermatophores in a polychaete, Hesionides arenarius FrIEDRICH. FrIEDrICH (1938) expected polychaetes to have mating with internal fertilization, mating with exteral fertilization and the liberation of sexual products into the water. The indirect transfer of spermatophores in the marine habitat has only been reported in the Halacarida (Schaller 1954, KIrChNer 1969). My observations suggest that at least one spionid polychaete also developed a fertilization system based on the indirect transfer of spermatophores.

The anatomy of spionid polychaetes was investigated in detail by SöDERSTröM (1920). In his description of the genital pouches ("Genitalprodukttaschen"), SöDERstRöm reported that some Spionidae closely related to Spio filicornis have specialised organs for the production of big cuticular bladders incorporating the gonoproducts. These may be the organs producing the pelagic spermatophores. Yet they seem to conform better to the "egg mass of jelly" as described by OKuDA (1943).

It is surprising that the spermatophores of a species of which RACHOR (1972) found more than 1000 individuals per $\mathrm{m}^{2}$ have not been found in plankton samples before. This may be due to the fragility of the spermatophores, which did not stand the sampling and fixation procedure.

\section{SUMMARY}

1. During culture experiments with marine invertebrates pelagic spermatophores were detected which looked like transparent toy balloons of $1.6 \mathrm{~mm}$ diameter. They were extremely fragile, which may account for the lack of previous reports.

2. The spermatophores never appeared singly. 10 of them were seen emerging from the sand at a place where the spionid Spio filicornis was living.

3. The shape and size of the spermatozoa conform to those of related spionids, which have spezialized organs assumed to be capable of producing pelagic spermatophores; while mating experiments were not conclusive, evidence suggests that the spermatophores were indeed the product of Spio filicornis.

4. Therefore it is expected that at least this spionid polychaete uses the indirect transfer of spermatophores in order to assure the fertilization of its eggs. The only group of marine organisms from which a similar behaviour is known are members of Halacarida. 
Acknowledgements: I wish to express my gratitude to Mr. P. H. SAHunNG for his help with the documentation of the material, to Dr. W. Westherde (Göttingen) for the determination of the polychaete and to Dr. E. Rachor (Bremerhaven), Dr. G. HarTmann-SchröDER (Hamburg) and Dr. R. vON HENTIG (Bielefeld) for going through the manuscript and giving me further information.

\section{LITERAT'URE CITED}

Franzen, A., 1956. On spermiogenesis, morphology of the spermatozoon, and biology of fertilization among invertebrates. Zool. Bidr. Upps. 31, 355-480.

FrIrdrICH, H., 1938. Polychaeta. Tierwelt Nord- und Ostsee 6b, 1-201.

GREVE, W., 1968. The "planktonkreisel", a new device for culturing zooplankton. Mar. Biol. 1, 201-203.

Kurchner, W. P., 1969. Zur Biologie und Okologie von Halacarus basteri basteri Johnson 1836 (Acari, Trombidiformes). Oecologia 3, 56-59.

Okuda, S., 1943. Studies on the development of Annelida Polychaeta I. J. Fac. Sci. Hokkaido Univ. (Ser.) 9, 115-219.

RACHOR, E., 1972. On the influence of industrial waste containing $\mathrm{H}_{2} \mathrm{SO}_{4}$ and $\mathrm{FeSO}_{4}$ on the bottom fauna off Helgoland. In: Marine pollution and sea life. Ed. by M. Rurvo. Fishing News Books, London, 390-392.

Schalifr, F., 1954. Die indirekte Spermatophorenübertragung und ihre Probleme. Forschn. Fortschr. 28, 321-326.

Söderström, A., 1920. Studien über die Polychaetenfamilie Spionidae. Diss. Uppsala, 286 pp. WESTHEIDE, W. \& Ax, P., 1964. Bildung und Ubertragung von Spermatophoren bei Polychaeten (Untersuchungen an Hesionides arenarius FrIEdRICH). Verh. dt. zool. Ges. 58, 196-203.

Author's address: Dr. W. GREvE

Biologische Anstalt Helgoland (Meeresstation)

2192 Helgoland

Federal Republic of Germany 